\title{
Using Stanford's Design Thinking Model at the Rural Village Level
}

\author{
Paul Lane \\ Grand Valley State University and UNAN Managua \\ KC Christopher \\ Engineering, Grand Valley State University
}

\begin{abstract}
A case history of a rural workshop using the Stanford Design Thinking Model in a remote part of the Rio San Juan Nicaragua. The program is run under UNICAM UNANManagua believed to be the largest program of its kind. It is a chance to see how both facilitators and participants can learn in very simple settings. It is a chance to understand what kinds of things are impacting the lives of rural people in their quest for the basics of existence such as food and water. Most of all it is a living action of the dream of bringing top level education to the rural people of Nicargua. All the action takes place in a simple rancho at the edge of the Rio San Juan where participants come by canoe, and by foot.
\end{abstract}

\section{WHAT IS UNICAM -- A DREAM FOR INNOVATION AND ENTREPRENEURSHIP?}

UNICAM (Universidad en el campo) has been the long-time vision of the Rector Ramona Rodriquez Perez of UNAN-Managua in Managua, Nicaragua. As a Dean and then as the Vice Rector General, she has tried to carry out the idea of "education for all". One of the areas that has been continually underserved when it comes to education are the rural areas, and thus, these became the focus of her educational mission. The idea of taking classes, resources, and faculty to the rural areas for classes was born, and UNICAM was created for this purpose. This idea has transformed the educational objectives from "education for all who can reach it" to the more inclusive "education for all". The objectives for the program are as follows:

1. Strengthen the capacities of young people in rural communities through access to higher education.

2. Encourage socio-economic cultural development in order to contribute to the reduction of poverty in the field of the most vulnerable populations in the rural sector.

3. Reduce the rural exodus through a sustainable educational strategy that strengthens the roots, satisfies the basic needs of socio-economic development and helps reduce poverty in the countryside. (Mendoza, 2019

A little about Nicaragua may help the reader grasp the importance of what is believed to be the largest UNICAM program the world. This is a country of a little over 6 million people and almost half live in what are defined as rural area. About $25 \%$ live in the capital city of Managua and the other 25\% in the larger cities of Estelí, Granada, Leon, Masaya, and Matagalpa.

The authors work with UNAN-Managua Nicaragua's leading university in terms of numbers of students and up and coming education. It has many colleges departments, a medical school, and four regional campuses in addition to its Managua locations. The University has been a Sandinista strong hold for many years. One of the focuses on Augusto Sandino and those who followed him was a focus on the rural people and trying to get them education and the 
opportunity to open their minds. It is with this goal in with this goal in mind that the Rector Ramona Rodriquez Perez supports the UNICAM program. It brings education to some of the most rural areas of Nicaragua.

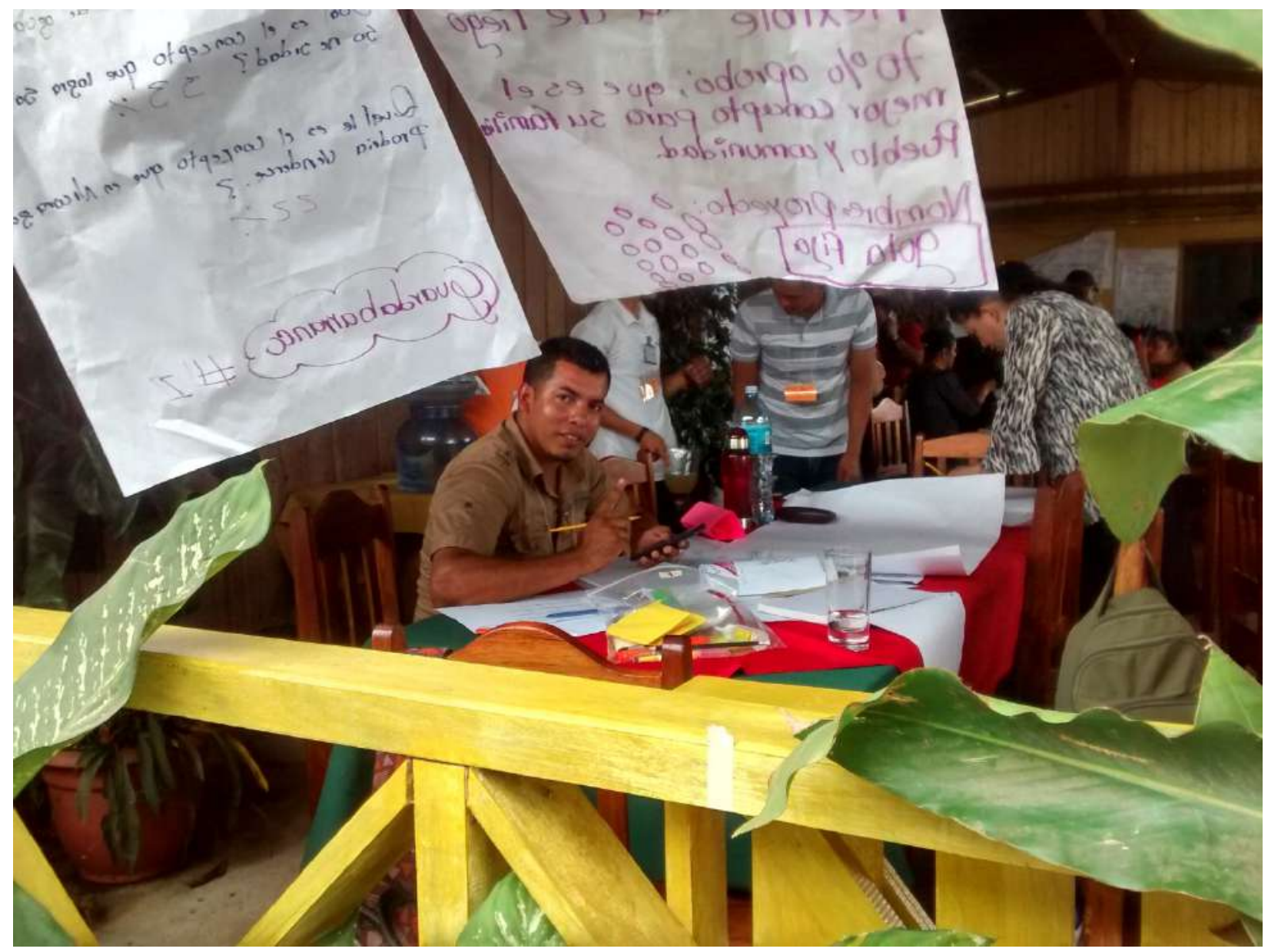

In 2010 the European Union committed funds to develop and expand this program in four countries in Latin America: Nicaragua, Mexico, Bolivia, and Columbia. (Ministry of Education Columbia 2010, http://www.farem.unan.edu.ni/?page_id=2701). The program in Columbia was launched with much fanfare but seems to have disappeared and may be in the process of being reconfigured. There is no support that Bolivia has launched its program. Additionally, there was to be a program in Mexico, but again, no literature was found to support that this program has been launched. After several years, the program has opened to other countries in the region, and in 2017 Puerto Rico was launching a program which is still in its infancy. Having built and sustained the UNICAM programs in most of the regions in their country, it appears that UNAN-Managua and Nicaragua are leaders in this innovative form of education for rural peoples.

In 2019 there were extensive UNICAM programs planned for three of the campuses of UNANManagua. In the Chontales region to the South, there are programs planned for Muelle de los Bueyes and in El Castillo on the Rio San Juan. In the Estelí region, UNICAM extends to the northern part of the country with several programs, the first, in Miraflor and the second, in San Juan de Limay and now Jalapa on the Rio Coco the border with Honduras. In the Matagalpa region, UNICAM extends to the East with three programs in Tuma La Dahlia, Rio Blanco, and Mulukuku. These regions cover hundreds of small, remote villages to provide programs, educational resources, and support to the people that live there. Figure 1 shows the origin and 
context of the UNICAM program. Figure 2 shows a map of each of the regions in the UNICAM program in Nicaragua.

Figure 1: Origins and contexts of the UNICAM program.

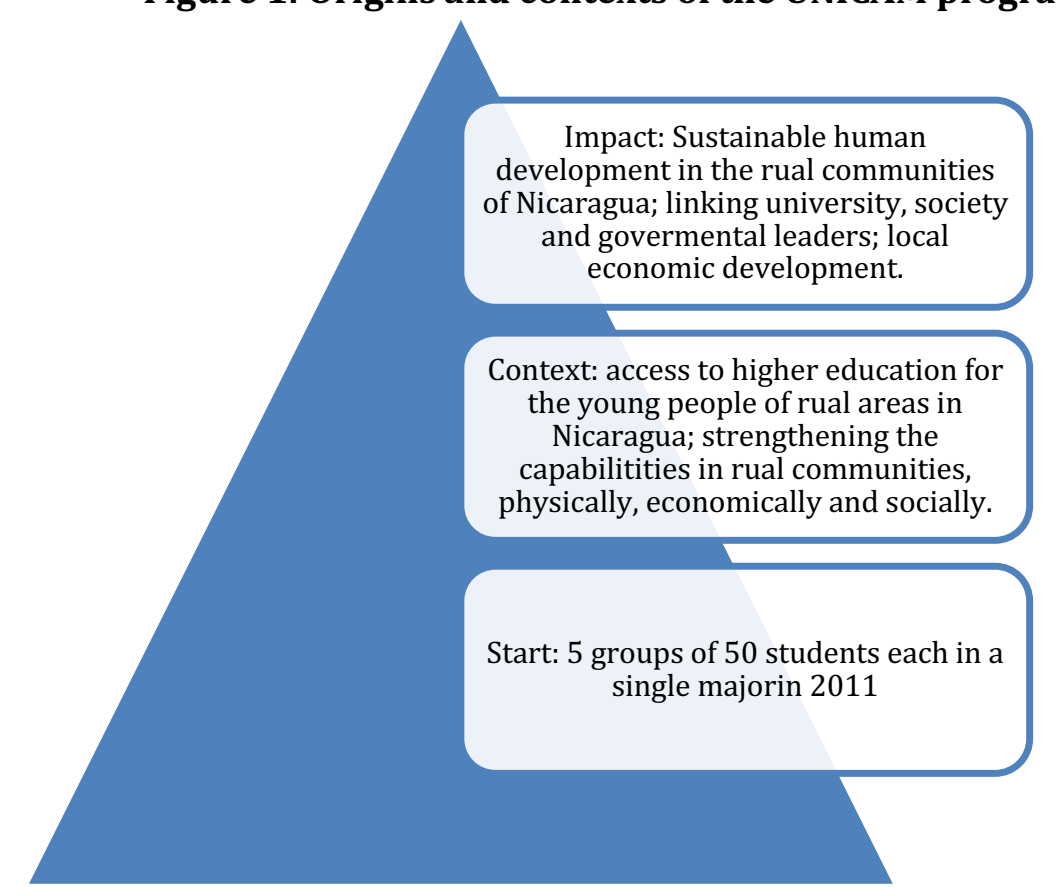

Source: Mendoza, Universidad en el Campo interpeted by the authors

Figure 2: Locations of the regions covered by the UNICAM program. Each region has a core team that develop content, Schedule the courses, and provide educational support to the rural communities.

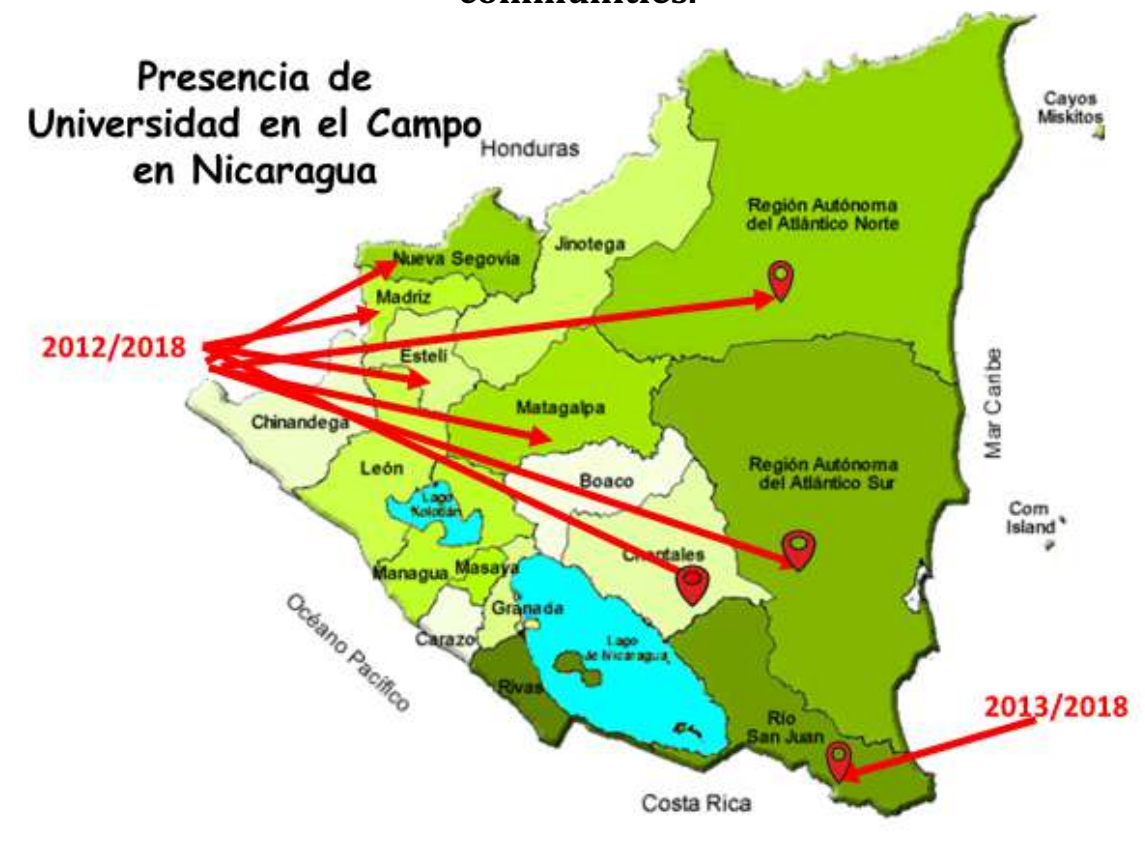

Source: Mendoza, Universidad en el Campo

UNICAM is the University reaching out to serve the very underserved. It is an example of University Innovation at UNAN-Managua that is really affecting lives. This program provides opportunities including the workshop subject of this paper to people living in remote rural areas. Increasing inclusion and access to all for postsecondary education is called for in the 
educational community. It is part of the UNESCO 2030 Objectives and was called for in Third Regional Conference on post-secondary education in Latin America and the Caribbean, (CRES June 2018). This program not only reaches a market that is not included in most university programs, it has an innovative funding model including both the university and local community sources. A Dream has become a reality.

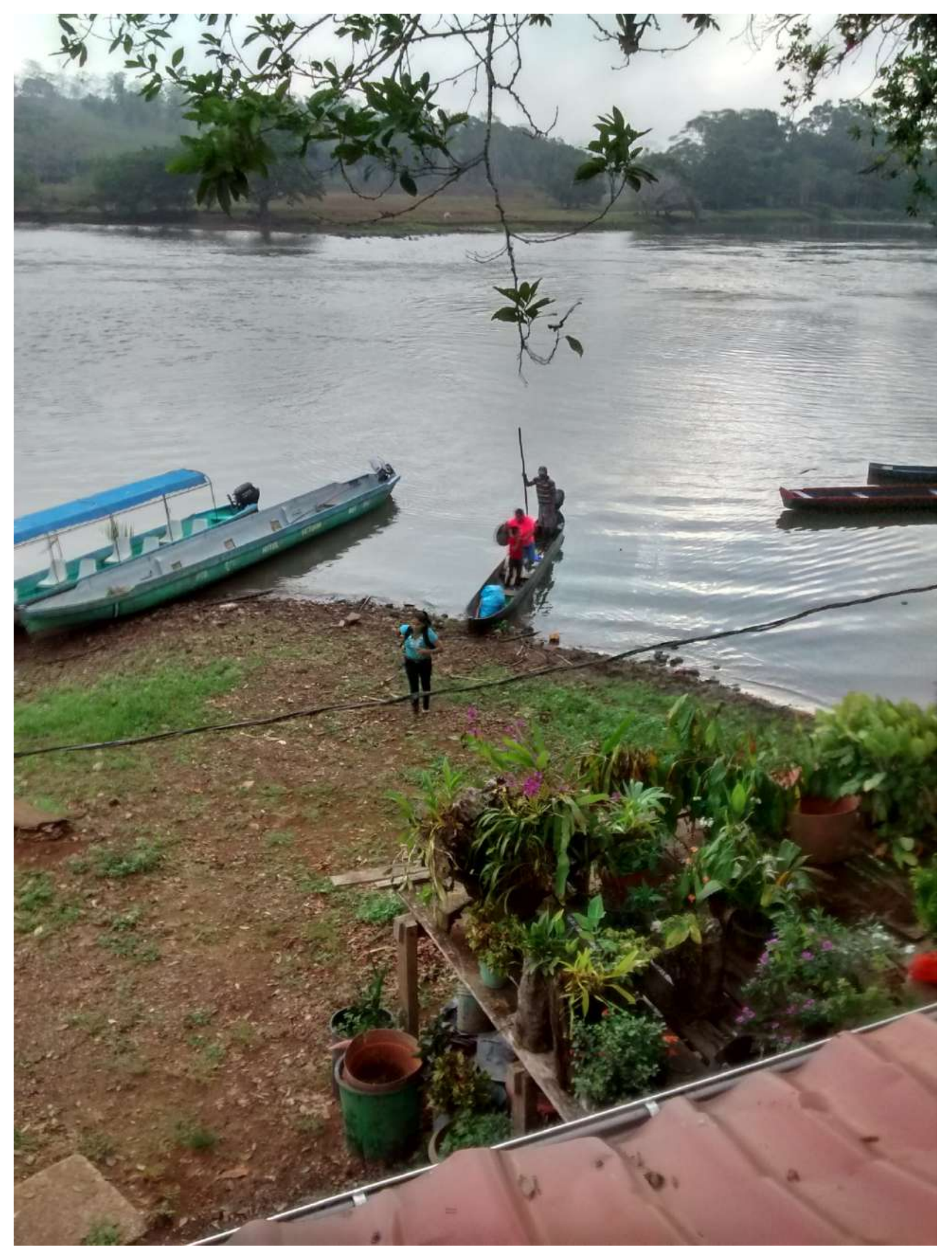


The rural communities served by UNICAM need educational opportunities. One can imagine how difficult it would be for a young student to leave their farm, home, and family, and make the long journey to UNAN-Managua or one of the FAREMs, the regional campuses. Nicaragua is not a huge country however it has a poor but improving infrastructure in terms roads. To give an example one of the authors works with the Mayangna Sauni AS original peoples. The leaders wanted to get their students into the university. After arriving from distant villages, the students had to board a school bus to ride 20 or so hours to Managua to take the entrance exams. It is an incredible hardship to have to travel like that and if accepted to be away from family and farm that great a distance. In many of these rural communities across Nicaragua there are no opportunities for university-level education. UNICAM offers several different programs, including the Majors shown in Table 1.

Table 1

Careers or majors offered by UNICAM UNAN-Managua (Mendoza 2019a)

\begin{tabular}{|c|}
\hline UNICAM Majors \\
\hline Administración de Empresas \\
Business Administration \\
\hline Desarrollo Rural Sostenible \\
Rural Sustainable Development \\
\hline Contabilidad Pública y Finanzas \\
Public Accounting and Finance \\
\hline Economía Agrícola \\
Agricultural Economics \\
\hline Enfermería Materno Infantil \\
Nursing for Mothers of Infants \\
\hline Enfermería Salud Publica \\
Public Health Nursing \\
\hline Física-Matemática \\
Math and Physics \\
\hline Lengua y Literatura \\
Language and Literature \\
\hline Teaching with an emphasis on Infants \\
\hline Técnico Superior de Enfermería \\
Advance Studies in Nursing \\
\hline Técnico Superior en Topografía \\
Advance Studies Surveying \\
\hline Turismo Sostenible \\
Sustainable Tourism or Eco Tourism \\
\hline Fourteen Majors currently \\
\hline
\end{tabular}

In addition, the leadership of UNICAM at UNAN-Managua as sought out exposure to other kinds of thinking to bring to these rural communities. One example has been Design Thinking, which is used to help encourage innovation. Design Thinking has seen a recent increase in its usage around the world, and the leadership of UNICAM developed a program in El Castillo focused on this idea. The authors were brought in to help facilitate this workshop, as well as learn how design thinking can be applied in rural communities.

For this program, UNICAM was able to garner community support, university support, and the support and energy of the participants to arrange this specific workshop on Design Thinking. This was no small effort, but the return on investment is hopefully to bring world class workshops, instruction, and techniques to some of the most remote locations in the country. 
In the program in El Castillo, which is the subject of this article, Design Thinking was used to solve problems related to water. While access to potable water seems to be a universal problem in rural Nicaragua, it was an especially interesting problem in a community surrounded by the Rio San Juan and the rainforest.

While the workshop used Design Thinking to focus on water issues, the real opportunity created for all the participants was to learn a new process for addressing problems in a more general sense. Design Thinking has been refined over the years and the model being used was that which is used by Stanford University. Before explaining the process, the authors would like to include a small introduction to the El Castillo community, for context.

\section{INTRODUCING EL CASTILLO}

On the journey to El Castillo, the facilitation team was able to see much of the region and learn a lot about the people that live there. While the team could have taken a panga or small boat from San Carlos, the team decided to travel much of the journey by bus, and therefore were able to take in many of the sights along the way. In addition to some intensive observation during the road trip, the team was also given the opportunity to stop and ask questions of the locals along the way.

The team learned that there were four major types of industry in the region that were all leading to deforestation and degradation of the environment. This in turn, lead to a decline in the quality of life. Many of these industries were intermingled and seemed to vary in size from small family run operations to much larger corporate operations. The four major types of industry observed in the region were:

\section{Gold}

The most recent industry to grow in the region, was Gold Mining. Gold mining itself requires cutting open the earth in spots where the color seems to change from the red clay to more of a yellowish color. There are some vertical or horizontal mining shafts, but most of the mines consisted of open pits that were like huge open wounds in the Mother Earth. The men were sweating in the heat of the day while swinging sledgehammers releasing the huge rocks from the ground, while others tried to break them into smaller rocks for putting in bags for processing.

The processing uses two chemicals which are not only dangerous to humans but very dangerous to the environment and subterranean water systems. Both, Cyanide (used for killing people in wars) and Mercury (a neurological toxin), are essential to the gold processing that goes on in the area from San Carlos to the Sabalo river which was traversed by bus. In addition to all the dangers of pollution there are the slag piles of left-over rock, soil, and dirt after it has been processed. These are often not disposed of in an environmentally conscious manner, and simply left out to wash into the river and water systems.

This Is not the only area in Nicaragua where this kind of gold mining exist. You see like pock marks as you fly over what is supposed to be the tribal home of the Mayangna people in north central Nicaragua as well. 


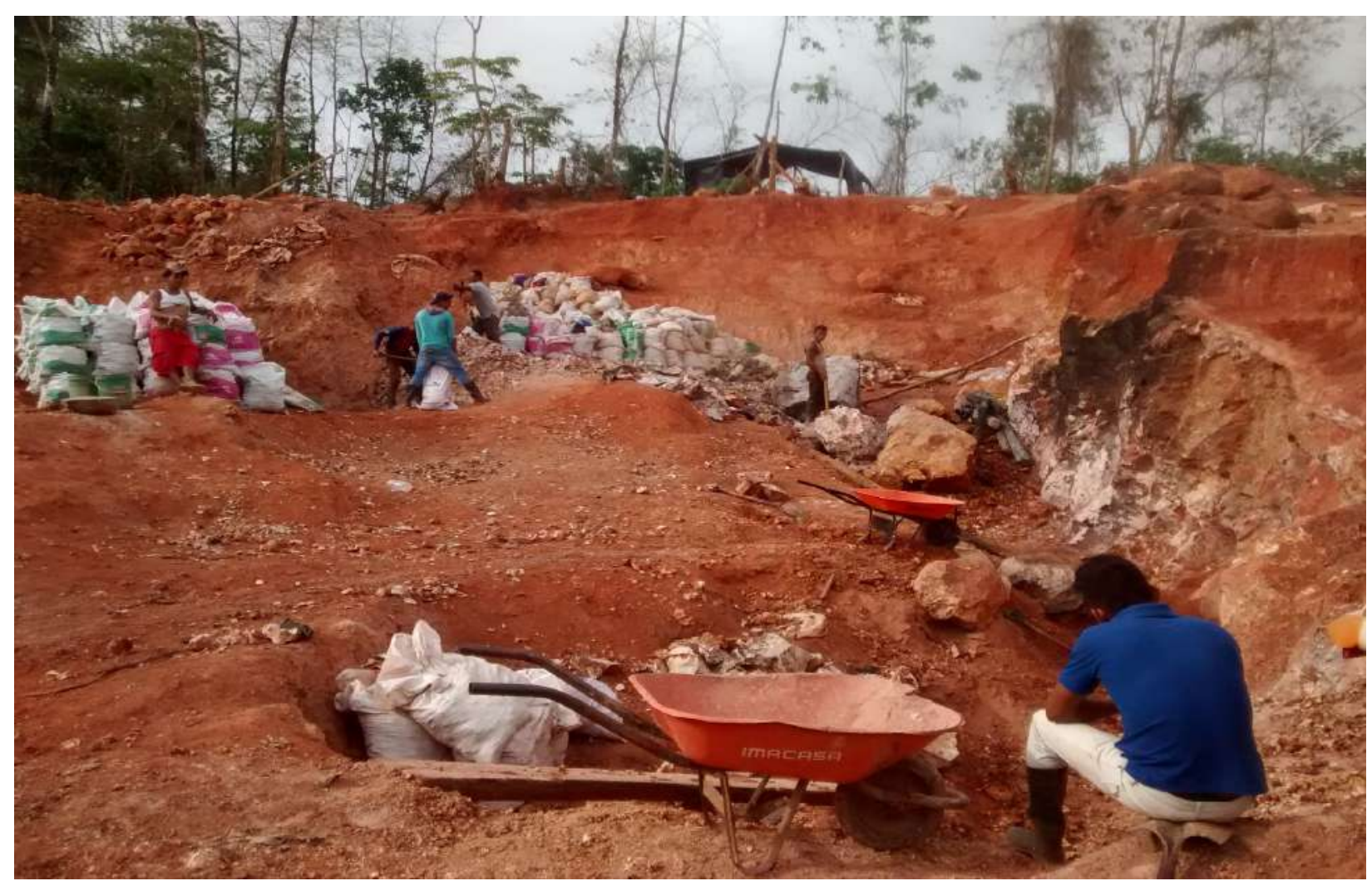

\section{Logging}

Logging is a huge issue in Nicaragua because it causes deforestation, pollution, and erosion. There are three reasons that the logging industry is growing in this region:

1. The creation of pastures for cattle cultivation as Nicaragua's and the world's desire for red meat increases each year. This type of deforestation is seen along the Rio San Juan all the way to the north to the lands of the Mayangna and the Miskito Indians. Landowners and Colonial invaders are cutting forests everywhere to create pastures for animals and farms.

2. Valuable hardwoods from the tropics are valued in many places around the world, and this causes a dismantling of the forest as these valuable trees are cut and a path cleared to drag them out of the forest and ship them around the globe.

3. The increase in population in Nicaragua means and increase in the demand for more framing for houses, more wood for furniture, and in many cases more wood for cooking. All of this leads to a slow but continuous type of deforestation when the trees are not replenished.

As the facilitation team drove along the dirt roads, they passed many logging trucks full of timber. As the bus travelled down the roads, it also passed kilometer after kilometer of cut wood stacked by the edge of the road ready to ship. Seeing all this deforestation was very relevant to the workshop on water, as deforestation changes the water pressure in subterranean aquafers. This can lead to contamination through run off from soil that is no longer held in place by trees. Additionally, where cattle are present and compacting the soil, this can lead to more rapid run off and soon gully's and other damages to the land which further change the access to water for local rural communities.

Some questions the research team wondered as they watch truck after truck of lumber were: where will the monkeys go? Where will the beautiful birds of Nicaragua end up - will the Guadabarranca go extinct? What will happen to the wild cats of this part of Nicaragua, the Tigre, Puma and the Panterra? 


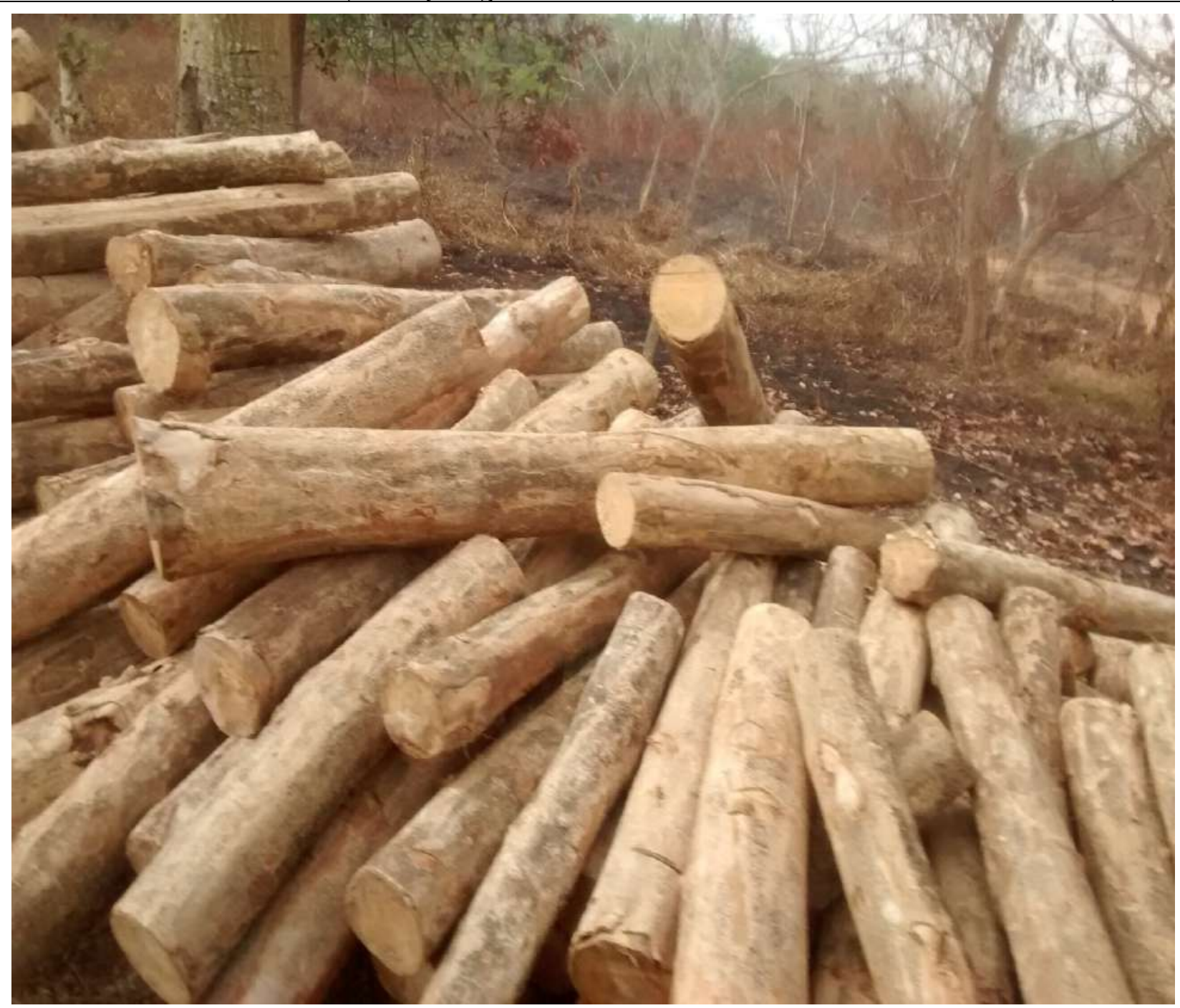

\section{Palm Oil Production}

On the river in Sabalo, which the team was ferried across, was a huge tanker ship waiting to take on Vegetable Oil. This is palm oil production from the nuts of the palms grown in great plantations. This means cutting the forest clear, and then planting the species of palm that generates the palm nuts that are so full of oil. This process destroys the native trees, species, and ecosystems that are natural in Nicaragua. Despite destroying the natural forest, the palm production industry brings some work harvesting, transporting, and processing the palm nuts into oil. 


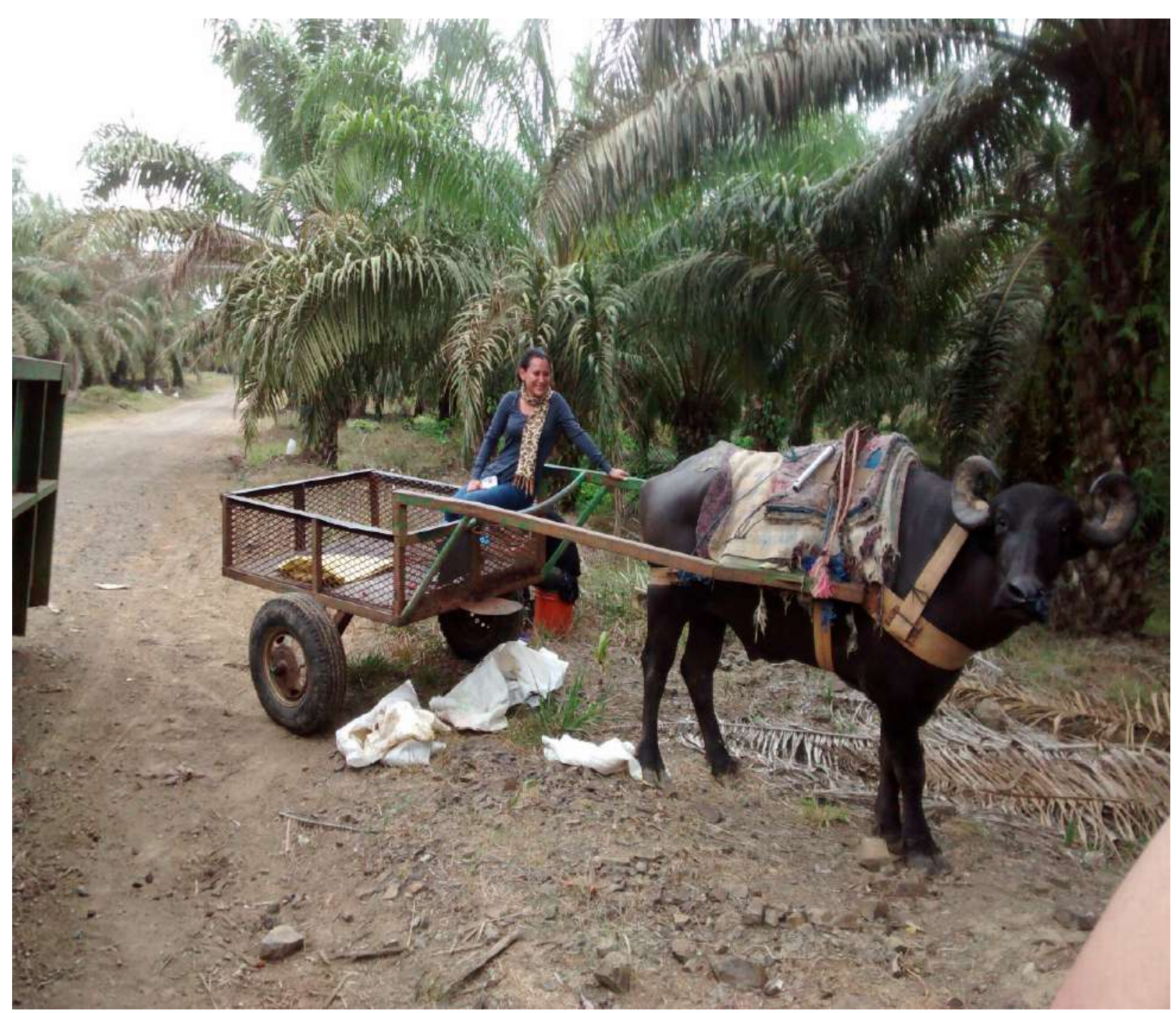




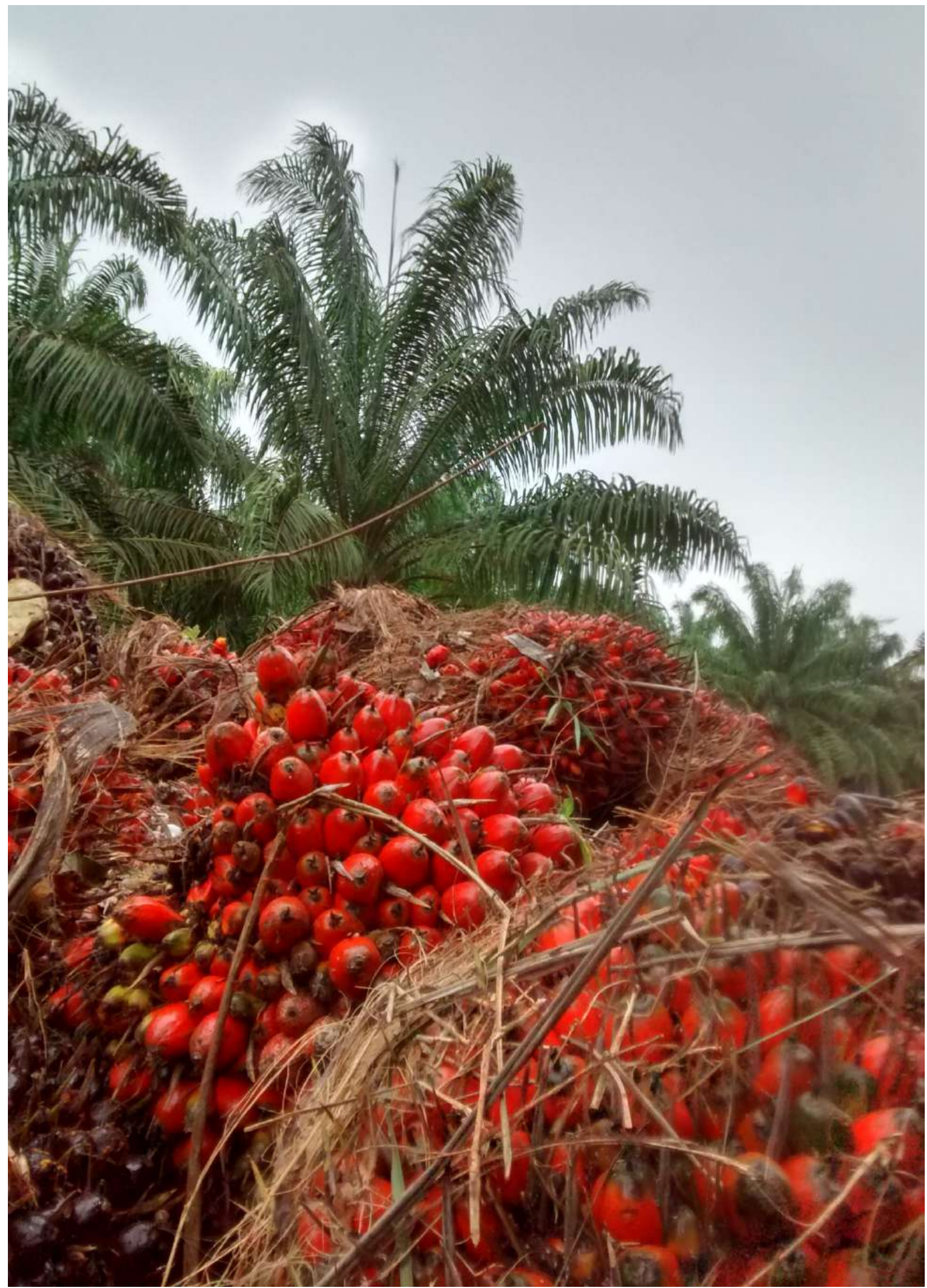

\section{Cattle}

Cattle are everywhere in this region of Nicaragua. Cattle are essential to supply the demands for beef in Nicaragua and beyond. Nicaraguans love red meat; however, many do not get the connection between deforestation and the consumption of red meat. In addition to the direct 
destruction to create pasture lands, there is the compactation of the soil by cattle making it harder to nourish underground water systems. In addition, there are the annual fires to burn the pastures and hopefully create greener pastures by adding nutrients to the soil. Unfortunately, many of these fires rage out of control, as this is done during the dry season, and damage many things including entire mountains covered in forests.

When you are facilitating in remote areas that are new to you this kind of exposure can really help you understand in some ways what the people are talking about and what their concerns are. It just takes a little cyanide to destroy a clear spring of water bubbling up from the ground. When the forest is cut in addition to all the other things it endangers the subterranean aquifers below. Recharging an aquafer requires the slow drip-drip of the multi-layer forest that is native to Nicaragua.

\section{THE WORKSHOP}

The facilitation and research team were pleased to have all this background before meeting the participants and hearing what they had to say about the water issues and their causes that they are experiencing. During the workshop, the participants mentioned every one of the things that were witnessed on the journey to El Castillo. Now that some context of El Castillo, and the Rio San Juan region, have been stated, the workshop event, its production, and its impact will be discussed.

\section{Set Up}

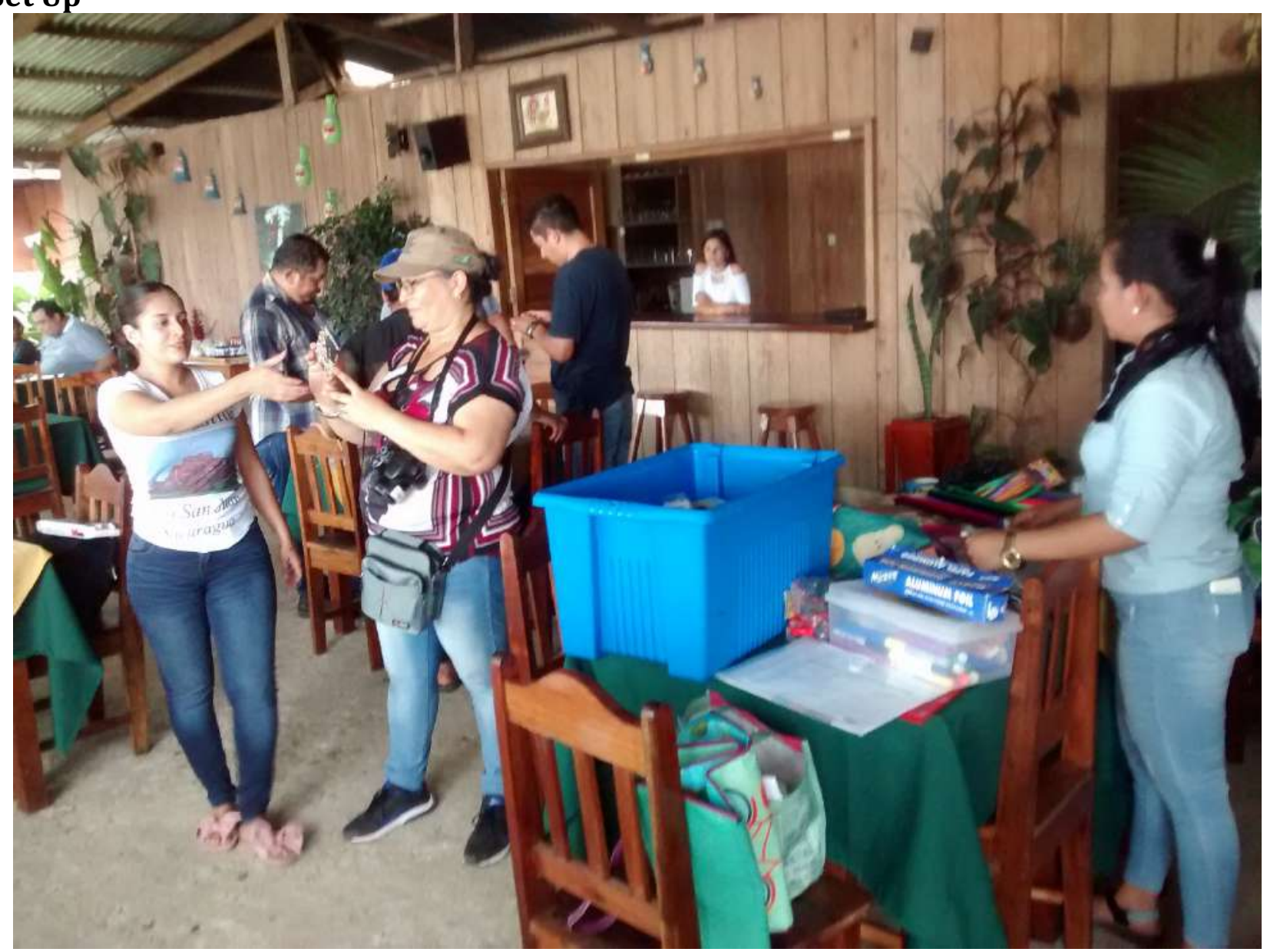

In this type of education where young parents and families walk a great distance to participate, many times families will travel as a unit which means, the facilitators also had children and even spouses in attendance. This was the case at El Castillo. The team arrived on a Thursday 
afternoon and set to work transforming the piles of supplies that had come by boat into useful packets for the workshop. There were five mentors from UNAN-Managua, Two very experienced mentors and three first time participants. They were all excellent. Once materials were organized, a training session was held to get the mentors and facilitators on the same page about what Friday and Saturday would look like.

Thursday evening and Friday morning people were trickling into El Castillo until all fifty-three participants arrived. Some came by pangas (open boats with motors), some by canoe and many on foot for two or three hours. They were all from surrounding communities in the Rio San Juan region. This the south of Nicaragua and south of the Rio San Juan lies Costa Rica.

The group of participants was unusually focused, staying on task through the entire two-day program. They worked hard to understand the process and to produce the best results possible. They seemed very interested in learning all that the facilitators and mentors had to share. Many were taking pictures every step of the way as a way of recording the process; hopefully to use again.

\section{Design Thinking}

Upon arrival, the participants were divided into small project groups consisting of 3-6 people. They used these teams to go through the entirety of the Design Thinking process focusing on developing sustainable solutions to water issues in the region. Figure 4 shows a diagram of the Design Thinking Process:

Figure 4: Design Thinking methodology from Stanford University

\section{Stanford Design Thinking Goes to El Castillo}

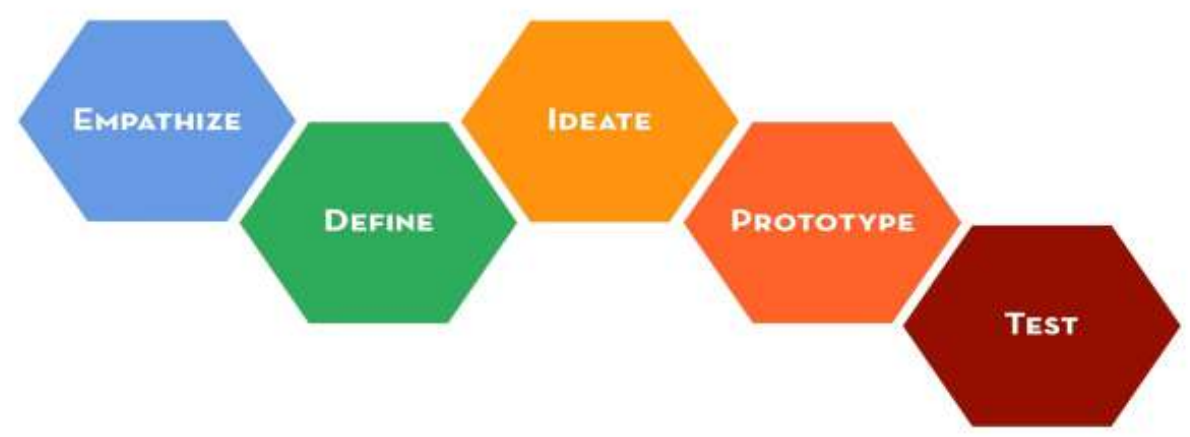

As was mentioned earlier, the concept of Design Thinking was a cornerstone of the workshop in El Castillo. The concept of Design Thinking has been developed over time by various groups, but the method used in this workshop was based on the Stanford University model. It has five parts to it including empathy, definition, ideation, prototyping, and testing, which were all used in this workshop.

\section{Empathy}

Empathy is the understanding of the clients, customers, consumers, or users. In this workshop the focus was on water in a region filled with a river, lakes, springs, and rivers, however there were still huge problems with water - specifically access to potable water. After explaining the model, the facilitators engaged those attending from surrounding communities in a brainstorm using post-it notes or stickies to identify water problems that they experience in their own 
communities. The facilitators encouraged participants to share stories and personal experiences around water to help everyone empathize with the situations of the locals.

There were many problems with water that came out.

Contamination

Chemical

From mining

From human trash

Biological

Cattle

Human

Other animals

Deforestation impact on water flows(surface and subterranean)

Cattle

Palm Oil Production

Mining

Access

One community had enough water because a private landowner had allowed them to tap into springs on his property.

There is clean water to be tapped below the surface but many times the spring mouths have been contaminated through human and animal usage.

\section{Definition}

The groups were encouraged to define the problem down to a smaller problem, as large problems are usually unmanageable for small communities trying to make a difference. This is very hard to do especially in a culture that was unfamiliar to some of the facilitators. In Nicaragua, the government is often expected to solve problems. It was hard for some participants to get the idea that they needed work on problems that they themselves could solve - including financing. 


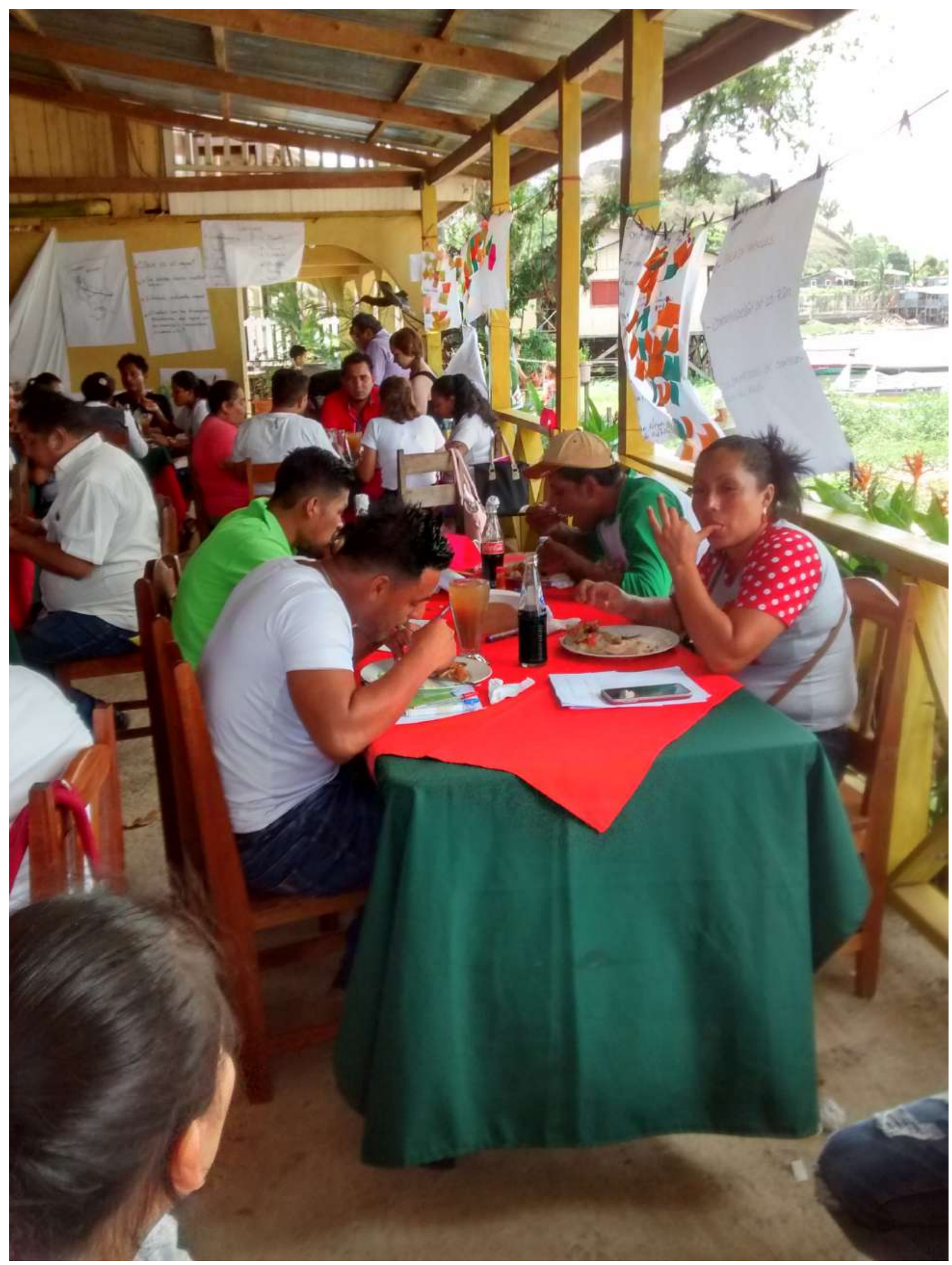

After lunch the participants were sent out into the community of El Castillo to verify and rate the three smaller problems that they had come up with from personal experience in the empathy stage. In this case the facilitators had prepared a survey that allowed them to quickly adapt it to their ideas. 
The participants returned from their excursion into the community asking opinions. There was much excitement as they began to put together their statistics group by group. It is always interesting to ask others what they see as problems, and it was not always the same as they personally saw. Trying to understand others in their context is what empathy is all about. The groups were then asked to narrow the list of ideas and develop a problem statement to help further define who was experiencing the problem, where it was experienced, and how it was experienced.

The results from the survey showed that there was lots of support for the idea that deforestation is a huge problem related to water. Support for trying to eliminate contamination; cleaning up sources of water. The goal of testing in the Stanford model is to be sure that you are meeting the needs of the potential clients. Thus, the testing after empathy and definition takes the participants back to confirming what the potential users are thinking.

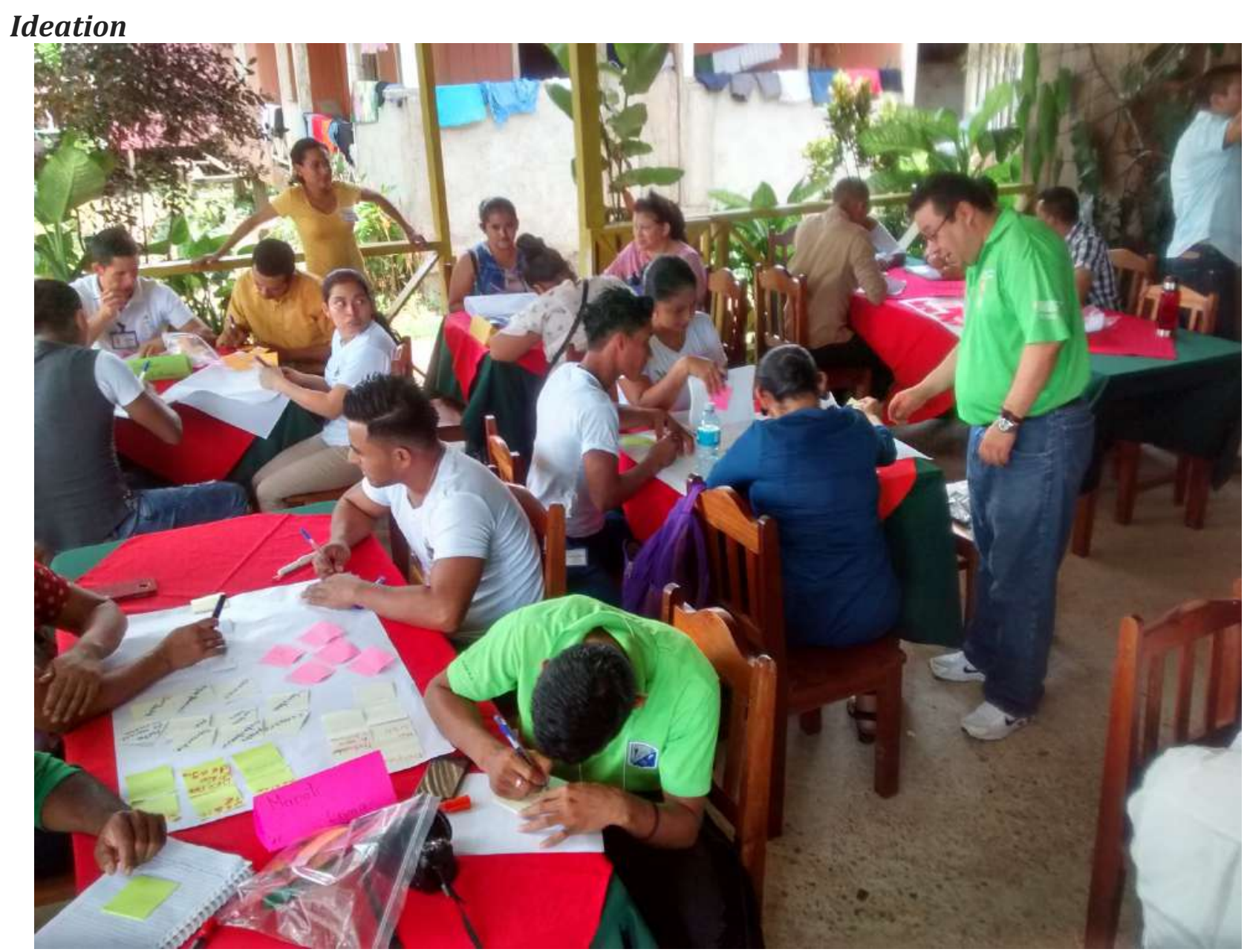

Once participants had defined and checked an idea, it was time to ideate. There were two rounds of ideation. The first is called Corners (Lane, 2018). This ideation is designed to generate hundreds of ideas, rapidly. Participants in their assigned groups of four or five plus the occasional child gathered around a large sheet of paper. In the center they placed the problem or opportunity that they wish to work on. Then each person takes a corner and if there are more than four someone takes a middle as well.

In 90 second bursts, people write as many ideas as possible. In this case they were thinking of possible solutions. The authors usually use four or five rotations. In this case there were four 
rotations and the number of ideas generated across the twelve teams was incredible, and can be found in Table 1:

Table 1

Ideas produced in Corners Ideation

\begin{tabular}{|l|l|}
\hline $\begin{array}{l}\text { Team name from El Castillo } \\
\text { The names are from local birds and animals }\end{array}$ & $\begin{array}{l}\text { Number of solution ideas generated using } \\
\text { Corners. }\end{array}$ \\
\hline Buffalo (water) & 64 \\
\hline Danto & 23 \\
\hline Guardabarranco & 23 \\
\hline Leon & 65 \\
\hline Logarto & 77 \\
\hline Pantera & 48 \\
\hline Puma & \\
\hline Sabalo & 87 \\
\hline Tigre & \\
\hline Toro & 70 \\
\hline Incomplete but a total & 457 \\
\hline
\end{tabular}

Of the teams reporting the average was 57 ideas. This is very close to what the authors get in the United States in class exercises. The large number of ideas generated gave teams the opportunity to think through what they wanted to do. Each person on each team was given three dots to vote for their favorite ideas. All on one or spread across the ideas. The teams then were able to choose the top three ideas from the Corners Ideation exercise.

These ideas were good as the participants in the workshop were part of the client market themselves. The second brainstorm used post it notes to come up with ideas for solutions to problems. In this case the participants have the space to write a more complete idea and affix it to the large paper. After each group had close to 50 possible solutions, an affinity process was used to group the solutions into some common themes.

\section{Prototyping}

In this workshop, the "spaghetti tower" exercise was used to get people used to building. This was immediately after lunch on the first day. Late that afternoon, after the ideations, the teams were asked to prototype something relevant to their solutions out of the contents of a bag of supplies that included the following:

Three of the plastic bottles that they had brought with them

Several sheets of colored paper

Several craft sticks

Tape

A yard of string

Glue

The results were an amazing collection of simple prototypes of plant nurseries (for reforestations), simple filters, and ideas for cleaning or keeping water cleaner as it comes from the ground. Figure 5 shows a picture of the spaghetti Towers, while figure 6 shows some of the creations from the plastic bottles. 


\section{Figure 5: One picture of Spaghetti Towers}

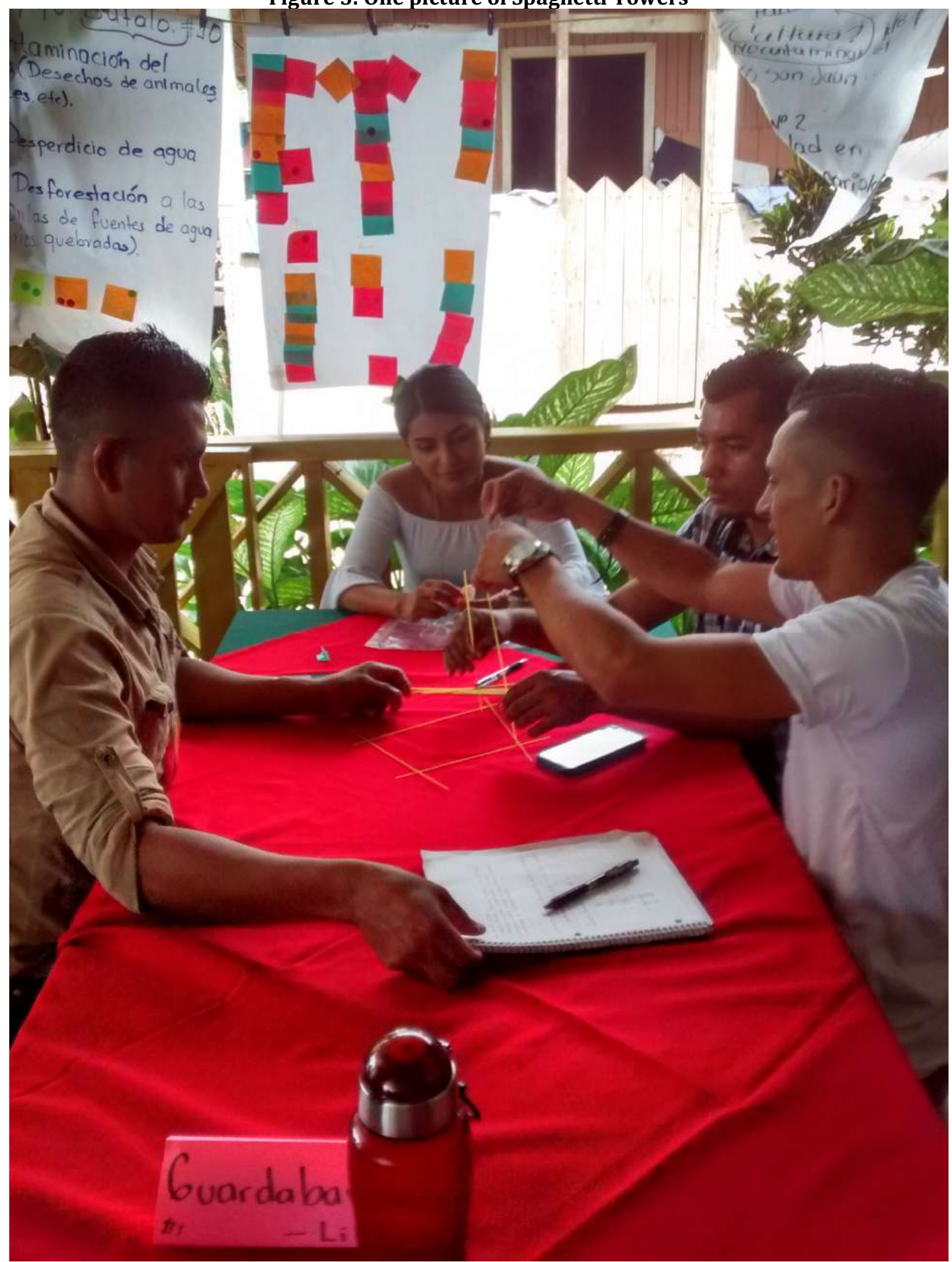




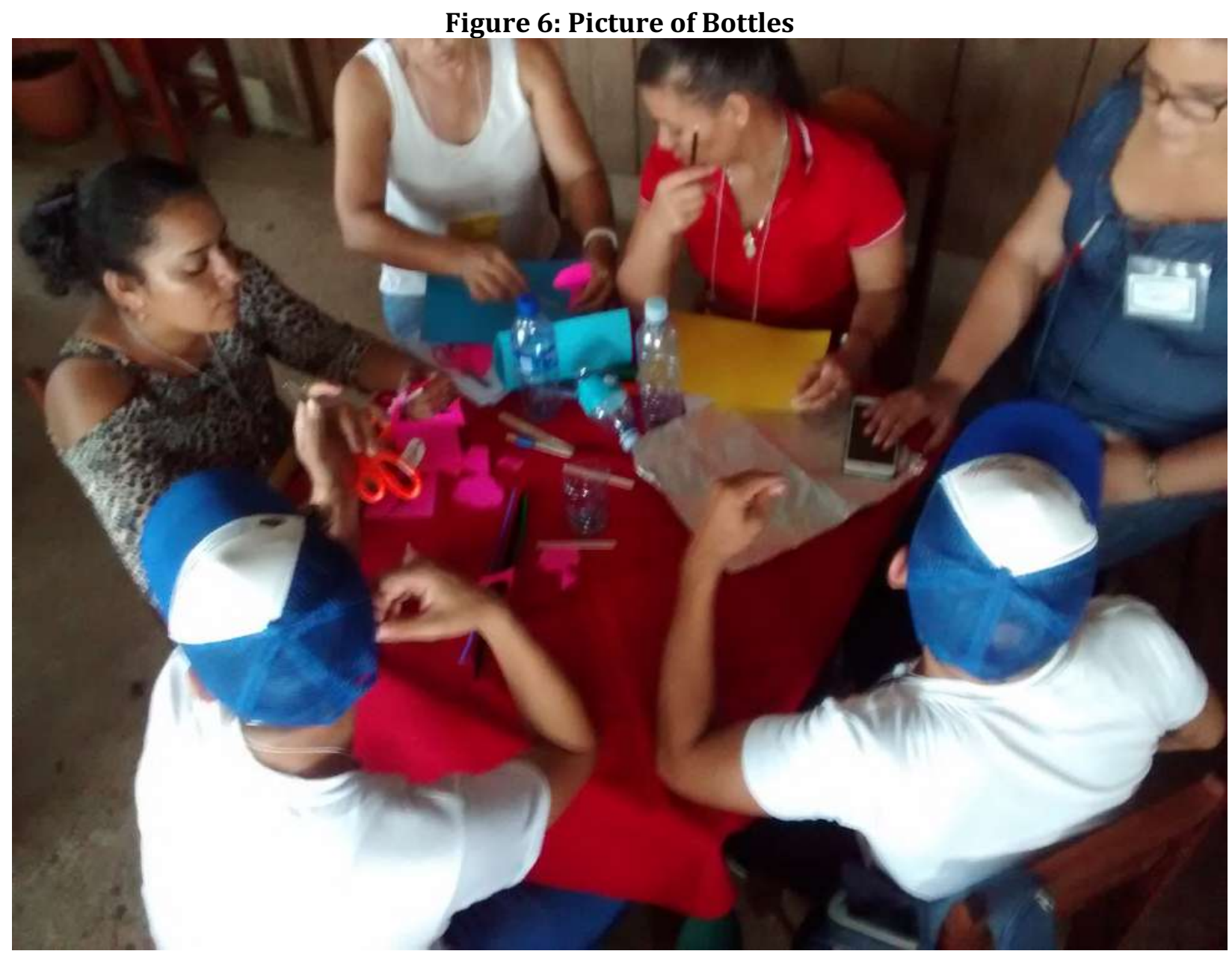

While focusing on what it takes to complete a solution, the participants were then asked to end their day by choosing the top three potential solutions that they had accumulated through their ideation. It is always amazing to see how the prototyping phase changes peoples thinking. When confronted with building a solution, sometimes perspectives seem to change.

Prototyping with things like the used plastic bottles is one way of prototyping. Another is to do develop realistic concepts. On the second day, Saturday, as we gathered immediately after a great breakfast for more than sixty of us at 7:00 in the morning the participants were asked to do some concept development.

For each of their top three ideas, the teams were to make a detailed sketch and explain it in simple words. The facilitators had made a model of how to do this which was blowing in the wind for all to see. It was amazing to see that everyone was there working, including the children who were making their own things or helping their parents. Out came the markers of all colors and much sharing amongst the teams as each did the best to develop their concepts.

Soon they were back out into the community with their sketches of solutions to get other's opinions. A return to empathy. Because the Design Thinking process is not linear, it is important to focus on empathy throughout the process. In this case, the teams did this by gathering other potential client's opinions on their solutions. Learning the process is what is so important for these community leaders as it will help them to solve problems in their communities in the future. 


\section{Test}

The results of the community testing were brought back, shared, and the teams had to select a solution that they would pursue. Before the final selection they were presented with the business model canvas and instructed to think about how their idea would get funded? This is always a hard topic in these communities where the hope is that the government will step in and help. In poverty it is hard to think about what you can do yourself. The teams were encouraged to gather more and more feedback on their solution, but also to test their value proposition, key characteristics, and funding channels.

\section{Presentation}

The final part of the workshop was to create a good model of the product idea and then present a very simple business plan. The teams worked before lunch and after lunch right up to the starting point at 1:30. At that point the room was reorganized to provide a wonderful viewing area and each team presenting their model and how it would work.

Considering the time and the limited resources, these models were incredible and some of their ideas were excellent. They seemed to have learned the process and have ideas of how solutions could really work in their community and for their peers. In addition, the teams had created very simple business elements including the Value Proposition, Channels of distribution, Market Segment, Cost and Price, as well as the investment that they thought might be necessary to get started. 


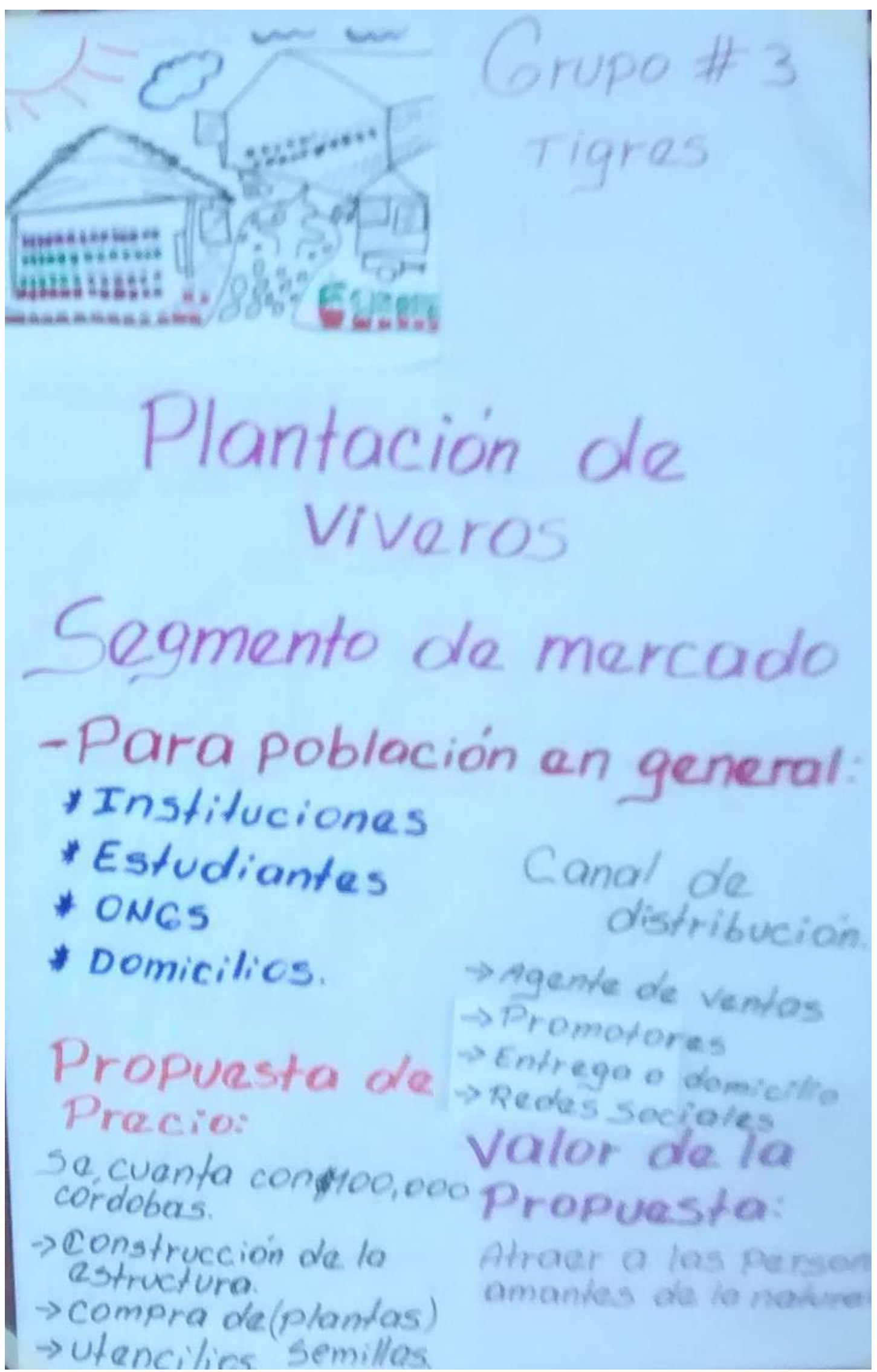




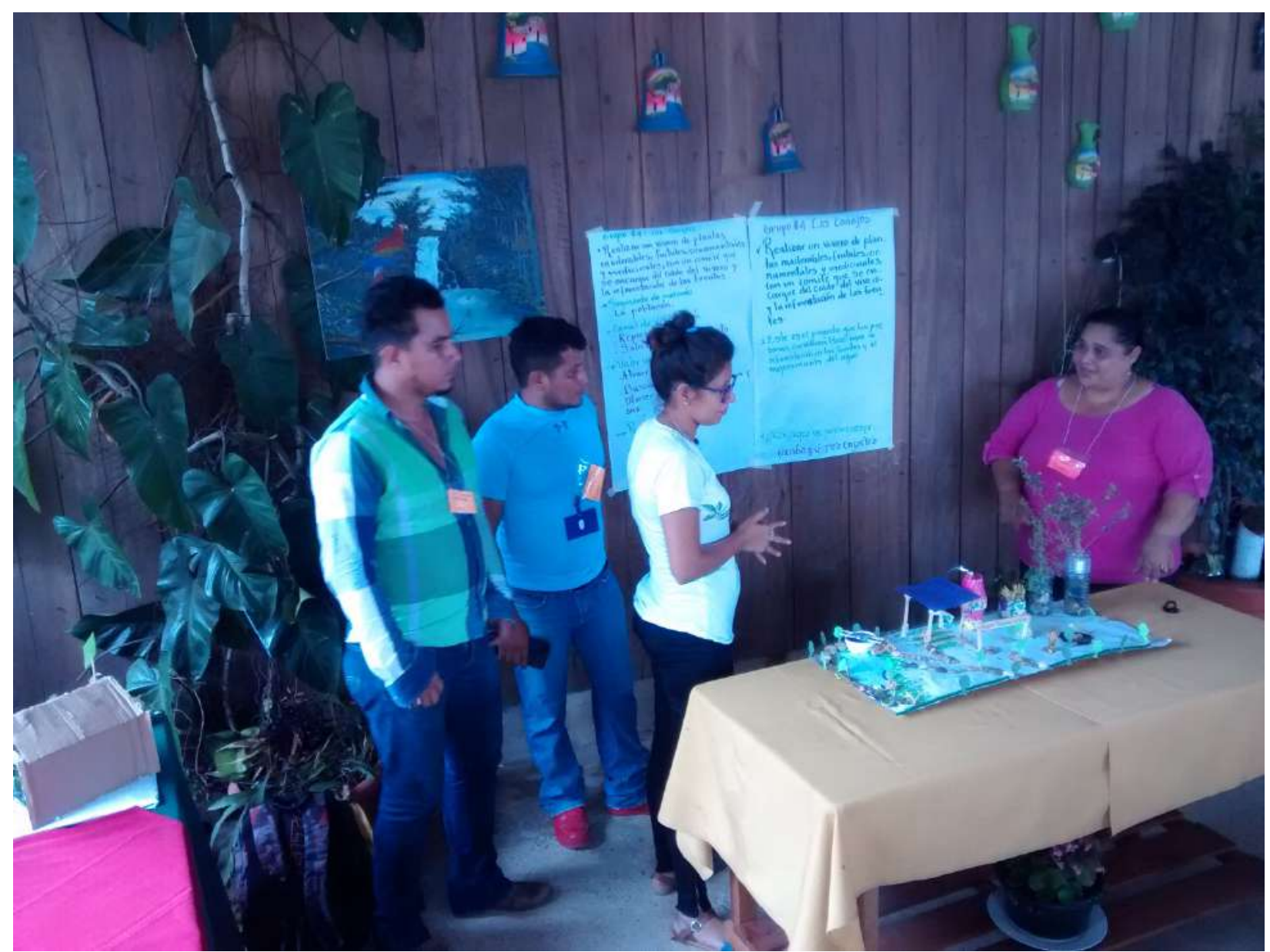

\section{CONCLUSION}

It is amazing to think that a journey of seven or eight hours from the Capital city in Nicaragua, to a very rural area along the southern border of Rio San Juan can create such an impact in a community. In a place so remote, that most of the participants have hiked or canoed miles to get to attend. In that meeting they can be introduced to the thinking processes of one of the world's greatest universities and not only grasp the ideas but really work intently with the process. This furthers the idea that Design Thinking is a powerful tool that can be used in almost any environment. 


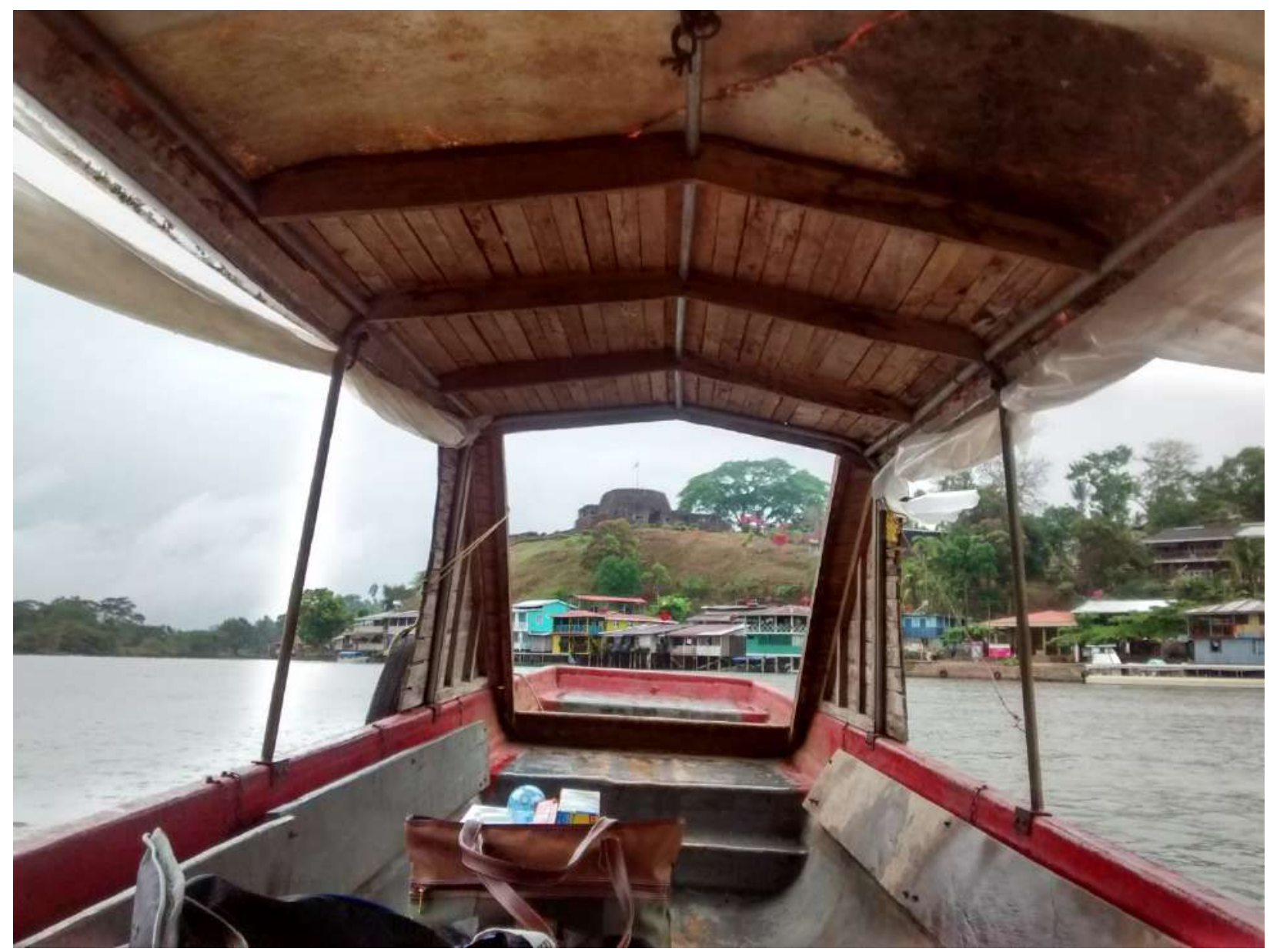

The participants were truly amazing. They were hard working, dedicated to learning, and most appreciative of the opportunity. Participants stayed engaged and shared ideas and information as they worked on their ideas. The facilitators were recognizing that solutions may have to be incremental in such an environment. What is important in this process is that they develop the incremental changes that they want. That they, the participants are empowered to improve their world with their resources. Outsiders should not try to determine what might be best for them - as they are the experts in their own region, experiences, and lives.

Perhaps in some small way these workshops contribute to the idea for which Sandino and many after him gave their lives to attempt to get the right to an education, to open minds, to create new opportunities for the rural peoples of Nicaragua. 


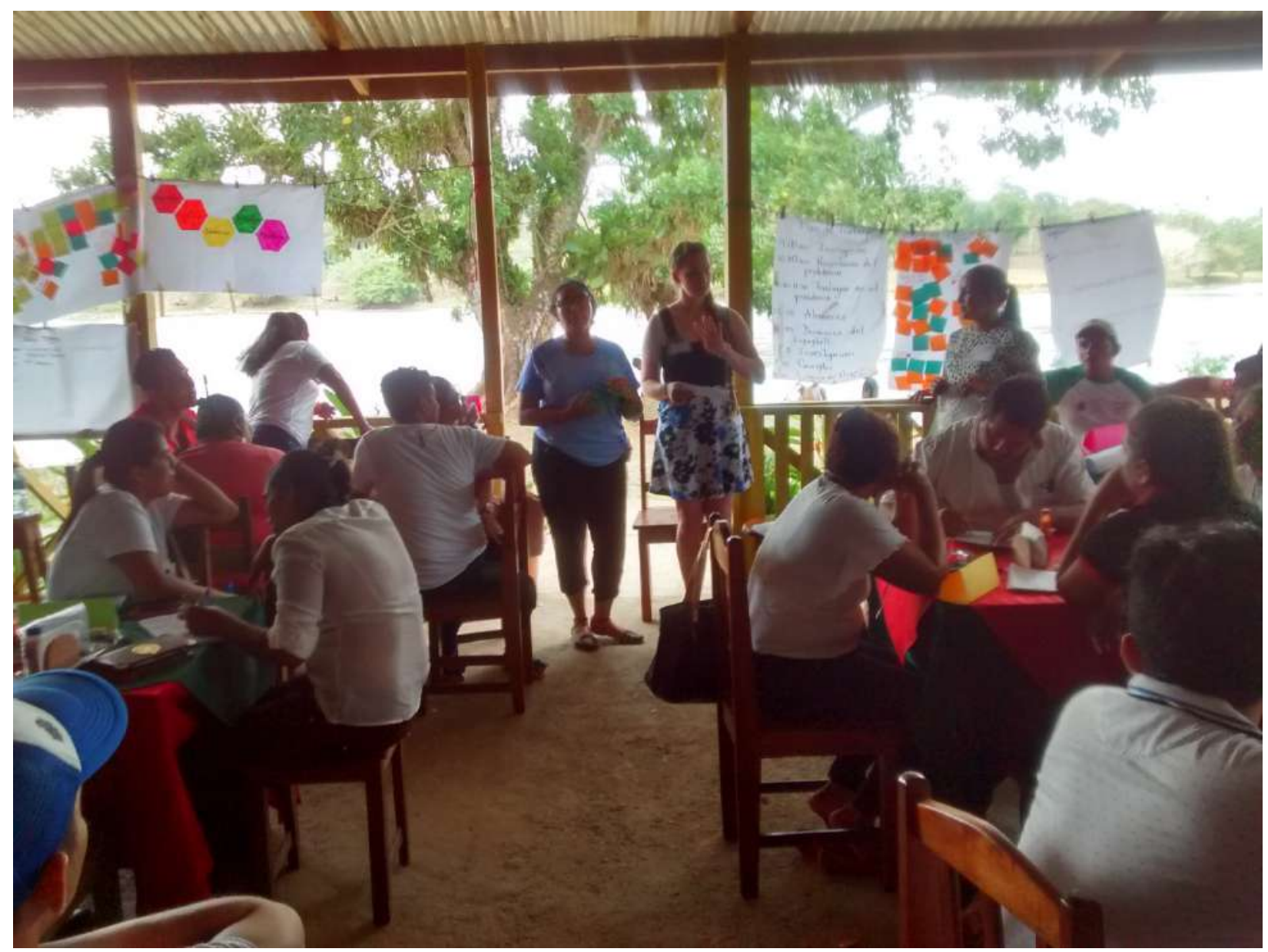

There is need for economic education and understanding how some things relate to others. The community needs to understand how the love of red meat leads to deforestation and more pastures, and how the employment in the palm oil industry is also tearing down the forest in order to create palm plantations. The same is true in the optimistic world of finding gold, and the devastation it creates. With a little economics, and understanding of connections, the participants will be able to better influence the use of their natural resources.

Finally, these are incredibly resilient people who are working hard to improve themselves and the lives of their families and communities. They may not have the formal education of the city dwellers, but through UNICAM and UNAN- Managua they are getting a chance to get world class education right in their own communities. 


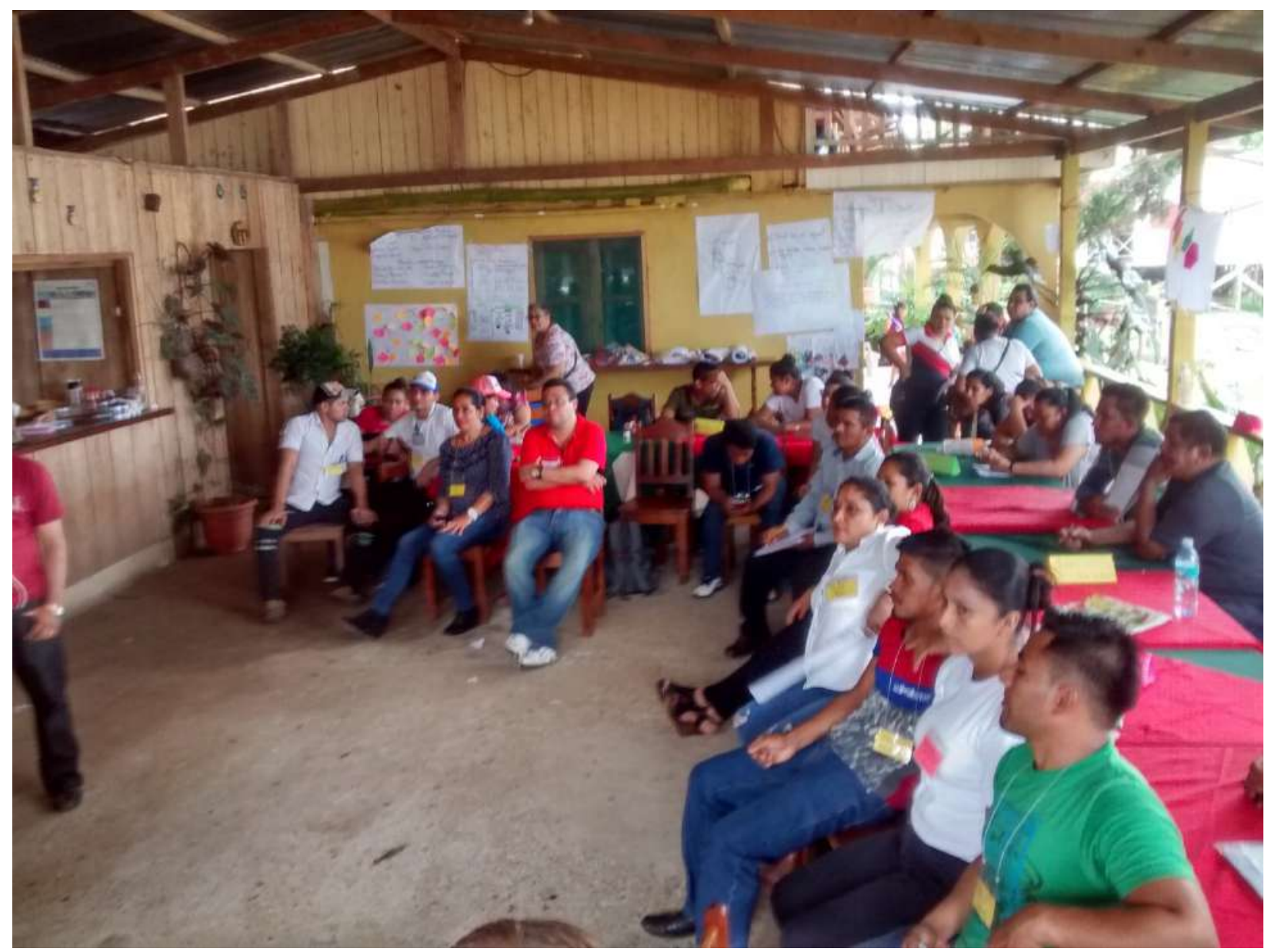

\section{References}

Congreso Universida 2018, the $11^{\text {th }}$ International Congress on Post-Secondary Education, Habana Cuba, Feb 12-16, $2018 \mathrm{http://www.congresouniversidad.cu/,} \mathrm{accessed} \mathrm{14.06.2018}$

CRES2018, Conferencia Regional de Educación Superior de América Latina y el Caribe-Córdova, 2018. cres2018@unesco.org.ve, accessed 14.06.2018

Design Thinking Process, Leland Stanford University, http://longevity3.stanford.edu/designchallenge/designthinking-process/ , accessed 20.6.2018

http://www.farem.unan.edu.ni/?page id=2701, Universidad en el campo, Accessed 14.07.2018

Globe, Global Conference on Business and Economics, http://globeconference.org/, Accessed 14.06.2018

Gómez, S. Ernesto. (2017). Creando la Universidad Innovadora en Nicaragua. Revista Nicaragüense de Antropología. Departamento de Antropología. Universidad Nacional Autónoma de Nicaragua, UNAN Managua. ISSN: 2520-9736. Disponible

en http://revistashumanidadescj.unan.edu.ni/index.php/Raices/article/view/221

Hienadz, Drahun, https://www.slideshare.net/Hienadz.Drahun/design-thinking-diagrams, accessed 9.062018

Laguna, J, “Desarrollando competencias en el modelo escuela nueva. Programa Universidad en el campo, UNANManagua, Nicaragua, Revista Científica de FAREM-Estelí. Medio ambiente, tecnología y desarrollo humano. № 19| Año 5 | Julio-septiembre, 2016

Lane, P. (2016). Creating the environment for innovation and entrepreneurship. International Entrepreneurship | Przedsiębiorczość Międzynarodowa, 2(2), 53-66. Retrieved from //pm.uek.krakow.pl/article/view/1114

Lane P, "Corners for Ideation-Engaging Students in the Ideation Process," Midwest Marketing Association, April 19th, 2018. in MMA proceedings

Lane P, "Five Pieces of Trash," Journal of Modern Education Review, Volume \& Number 12, pages 833 to 840 December 2017.

Lane P. EMPATHY THE FIRST STEP IN DESIGN THINKING, ICERI2017 Proceedings, pp. 4956-4962. .(2017) 
Lane, P., \& Christopher, KC. (2020). Using Stanford's Design Thinking Model at the Rural Village Level. Advances in Social Sciences Research Journal, 7(1) 192-216.

Lane P. A PEDAGOGY OF INTERDISCIPLINARY INNOVATION, INTED2016 Proceedings, pp. 4692-4698. (2016)

Mendoza, Claudia, Universidad en el Campo "Una alternativa de formación superior para jóvenes rurales de Nicaragua," Feb 8, 2019 Presentación.

Mendoza, Claudia, Programa: "Universidad en el Campo," 2019a http://www.manfut.org/RAAN/mulukuku.html, accessed 3.1.2018

Ministry of Education Columbia, "Universidad en el Campo, proyecto de la U. de Caldas para Latinoamérica," Martes, 02 de Noviembre de 2010, https://www.mineducacion.gov.co/cvn/1665/w3-article-253134.html, CCESSED 14.07.2018

Mendoza, Claudia, Universidad en el Campo "Una alternativa de formación superior para jóvenes rurales de Nicaragua," Feb 8, 2019 Presentación. 